\title{
Influences of Fund Transfer on Financial Performance and Market Share of Commercial Banks Listed At the Nairobi Securities Exchange, Kenya
}

\author{
Tarus Kenneth ${ }^{1}$, Mr. Njenga Gitahi Samson ${ }^{2}$, Prof. Peter B. Kibas ${ }^{3}$, \\ Prof. Ronald Chepkilot ${ }^{4}$, Dr. Joel Koima ${ }^{5}$ \\ ${ }^{1,2}$ Department of Business and Economics Kabarak University, Box 3270-20100, Nakuru-Kenya \\ ${ }^{3}$ Presbyterian University of East Africa University \\ ${ }^{4,5}$ Department of Economic and Business Studies Kabarak University, Box 3270-20100 \\ Nakuru-Kenya
}

\begin{abstract}
Technology has been the key driver of change in how the banking industry operates by complementing services offered, such as check books, ATMs, voicemail/landline interfaces, smart cards, pointof-sale networks, and internet resources. Such services subsequently influence person to person $(P 2 P)$ mobile money transfer (MMT), pay bill services, loan to customers and access to a wide range of banking services e.g. a/c balances, mini statements, transfer of money from one's mobile line a/c to one's own bank account. All these have the aspects of market share and financial performance of commercial banks. This study sought to determine the influences of mobile fund transfers on the financial performance and market share of commercial banks. The objectives of the study was to examine how various mobile money services transactions' impact on the performance of commercial banks; establish the effect of accessibility to mobile money services and finally determine the effect of efficiency and proficiency of mobile money services on the performance of commercial banks. The study adopted a survey study. The target population of the study was the 11 listed banks. The key study instruments used to collect primary data were questionnaires. Quantitative analysis was analyzed through descriptive statistics such as measure of central tendency that generated relevant percentages, frequency counts, mode, and median and mean where possible. To test for the strength of the model and the effects of mobile banking on the financial performance of commercial banks in Kenya, the study conducted an Analysis of Variance (ANOVA). From the regression model, the study found out that there were fund transfer variables influenced positively the financial performance of commercial banks in Kenya. The study found out that the intercept was 1.076 for all years. The independent variables that were studied explain a substantial $75.1 \%$ of financial performance of commercial banks in Kenya as represented by adjusted R2 (0.751). The study therefore concludes that mobile banking fund transfer positively and significantly affects the financial performance and market share of commercial banks in Kenya. The findings revealed that many mobile banking products are being offered by banks such as Fund Transfer between Accounts/ E-funds transfer, Bill Payment, order for cheque books and bank statements and therefore concluded that the financial performance of the banks that provide these mobile banking products has improved because they ensure efficiency of the banking services. The study recommends that policy makers consider mobile banking in their formulation of policies because of the technological developments and the expected switch from physical branch networks to technologically supported banking services. The study further recommends that commercial banks keep adopting and using mobile banking in their operations because the number of people with access to a mobile hand set is increasing every day.
\end{abstract}

Keywords: Commercial Banks, Financial Performance M-Payments, Market Share.

\section{INTRODUCTION}

\subsection{Background of the Study}

The move from traditional banking to mobile banking has been beneficial to both the banks and customers as it reduces operating cost of the institution and its convenient and cheap as lesser fees are charged on mobile transaction. Tiwari, Buse and Herstatt (2006) define mobile banking as any transaction, involving the transfer of ownership or rights to use goods and services, which is initiated and/or completed by using mobile access to computer- mediated networks with the help of an electronic device. They further indicate that mobile banking refers to provision and availment of 
bank-related financial services with the help of mobile telecommunication devices. The scope of offered services may include facilities to conduct bank and stock market transactions, to administer accounts and to access customized information from the bank. Mobile banking is the provision or availment of banking services with the help of mobile devices. Bank has had to adopt technological change to remain competitive. In search of competitive advantages in the technological financial service industry, banks have acknowledged value of differentiate themselves from others financial institution through new service distribution channels (Funds Transfer: This is the Immediate Payment Service is an interbank electronic instant mobile money transfer service through mobile phones. The beneficiary account is credited immediately when a Fund Transfer request is made through your Mobile phone / Internet Banking.

\subsection{Statement of the Problem}

Offering of selected banking services through third parties appointed by the banks is expected to be one of the solutions to reaching sections of the disadvantaged in society providing them with affordable financial services and access to credit (Beck, 2008). With a wider distribution of agents and their availability in nearly all towns and shopping centers as opposed to the limited traditional branch network, it is expected access to financial services should become more enhanced. Due to the huge savings made by reaching people without the expense of having to build branches, employ staff and incur the various other expenses of running a branch, it follows that financial services at these points should be offered at slightly lower prices and in addition benefits those who are geographically disadvantaged by availing the services closer to them. To the banking industry besides the cost savings, banks have penetrated and reached people they would never have reached particularly in the very remote areas (Kimenya, 2002).

According to Ignacio (2009), reaching the unbanked people and areas has been a major challenge. Occasioned by harsh climatic conditions, rough terrain, rural and poor regions are the worst hit (Kimenya, 2002). Very few financial institutions have the will to go into these areas especially bearing in mind that the places with such harsh conditions also attract fewer people thus the population densities there are very low, Financial institutions are not willing to spend large amounts of resources building branches which will not serve adequate numbers for them to break even profit wise. With this in mind banks have since adopted M-banking and entrusted them with some services as their agents thereby rendering themselves principals. An agent is expected to carry out the duties assigned to him/her by his/her principal. Banks are just like other businesses but their product just happens to be money. Other businesses sell services; banks sell money in the form of loans, certificate of Deposits (CDs) and other financial products. They make money on the interest they charge on loans because that interest is higher than the interest they pay on depositors' accounts. To achieve this banks have entrusted agents with some duties such as opening of new accounts which will in turn increase their market share and deposit taking. It is therefore evident that banks depend on M-banking to improve on their market share as well as increasing their deposit volumes. Despite the relevance of agents to the banking sector, research into the field remains scanty. Kamau, (2012), undertook a study on the relationship between m-banking and financial performance of banks in Kenya and established negative and weak correlation between the two. Mwangi, (2011) sought to establish role of M-banking in the performance of commercial banks in Kenya and established that cost effectiveness (infrastructure, human resource and security cost) associated with agency banks positively influence banks financial performance. Kithuka (2012), studied factors influencing growth of M-banking in Kenya and established that convenience of its technology, accessibility and cost has influenced its use. To bridge the existing knowledge gap it is worth carrying out a study to find out whether commercial banks have achieved their financial goals by embracing M-banking.

\subsection{Objectives of the Study}

The objectives of the study was to:

1. Examine how various mobile money services transactions' impact on the financial performance and market share of commercial banks.

2. Establish the effect of accessibility to mobile money services on the financial performance and market share.

3. Determine the effect of efficiency and proficiency of mobile money services on the financial performance and market share of commercial banks. 


\subsection{Research Hypotheses}

This paper focused on addressing the following three research hypotheses:

$\mathbf{H}_{01}$ : Money Services Transactions have no significant effect on financial performance and market share of commercial banks in Kenya.

$\mathbf{H}_{\mathbf{0 2}}$ : Accessibility to mobile money services has no significant effect on financial performance and market share of commercial banks in Kenya.

$\mathbf{H}_{\mathbf{0 3}}$ : Efficiency and Proficiency have no significant effect on financial performance and market share of commercial banks in Kenya.

\section{LITERATURE REVIEW}

The study was grounded on three theories:

\subsection{Financial Intermediation Theory}

Current financial intermediation theory builds on the notion that intermediaries serve to reduce transaction costs and informational asymmetries. As developments in information technology, deregulation, deepening of financial markets, etc. tend to reduce transaction costs and informational asymmetries, financial intermediation theory shall come to the conclusion that intermediation becomes useless Financial intermediation is a process which involves surplus units depositing funds with financial institutions who then lend to deficit units. Bisignano (1992) identified that financial intermediaries can be distinguished by four criteria. First, their main categories of liabilities or deposits are specified for a fixed sum which is not related to the performance of a portfolio. Second, the deposits are typically short-term and of a much shorter term than their assets. Third, a high proportion of their liabilities are chequeable which can be withdrawn on demand and fourthly, their liabilities and assets are largely not transferable. The most important contribution of intermediaries is a steady flow of funds from surplus to deficit units.

\subsubsection{Modern Economics Theory}

Modern economics also looks at items such as the role of demand, money supply, and its effect on growth or monetarism and free trade. Modern economics has gone far in discovering the various pathways through which millions of expectations of, and decisions by, individuals can give rise to emergent features of communities and societies like rate of inflation, productivity gains, and level of national income, prices, and stocks of various types of capital, cultural values, and social norms. Two factors make economic theory particularly difficult (Sohail and Shanmugham, 2003).

\subsubsection{Bank-led Theory}

In the most basic version of the bank-led theory of branchless banking, a licensed financial institution (typically a bank) delivers financial services through a retail agent. That is, the bank develops financial products and services, but distributes them through retail agents who handle all or most customer interaction (Ivatury \& Lyman, 2006). The bank is the ultimate provider of financial services and is the institution in which customers maintain accounts. Retail agents have face-to-face interaction with customers and perform cash in/cash-out functions, much as a branch-based teller would take deposits and process withdrawals (Owens, 2006).

This model promises the potential to substantially increase the financial services outreach by using a different delivery channel (retailers/ mobile phones), a different trade partner (Chain Store) having experience and target market distinct from traditional banks, and may be significantly cheaper than the bank based alternatives. In this model customer account relationship rests with the bank (Tomaškova, 2010).

The bank lead theory is related to the study as it focuses on how financial institutions like bank deliver their financial services through a retail agent, where the bank develops financial products and services, but distributes them through retail agents who handle all or most customer interaction. For example; Family bank of Kenya distributes its financial product through its Pesa Pap agent, where the agent has face-to-face interaction with customers and perform cash-in/cash-out functions, much as a branch-based teller would take deposits and process withdrawals. 


\subsection{Bank Performance Indicators}

Profit is the ultimate goal of commercial banks hence all the strategies designed and activities performed thereof are meant to realize this grand objective. To measure the profitability of commercial banks, there are variety of ratios used of which Return on Asset, Return on Equity and Net Interest Margin are the major ones (Murthy and Sree, 2003).

\subsection{Conceptual Framework}

According to Orodho, (2009) a conceptual framework is a model of presentation where the relationship between variables in the study is represented diagrammatically. Independent variables are factors that mitigate M-banking and include; Various money service transaction, Accessibility and finally Efficiency and proficiency. All these factors affect financial performance and market share whose measures are volume of deposits and number of new customer accounts opened.

Volume of deposit will be measured by amount of cash flows (withdrawals against cash deposits) that the agency receives from the customers. Customer base will be measured by number of new customers that register for M-banking and also by the number of customers that have embraced Mbanking services without necessarily going to the bank. This will spell out the presence or lack of security, transparency and accountability in the agency system.

The study will also underscore the contribution of intervening variables such as socio-economic and political systems which may be beyond the control of the management of commercial banks.

Independent Variables

Dependent Variables

\begin{tabular}{|l|l|l|}
\hline $\begin{array}{l}\text { - Various money service } \\
\text { transaction } \\
\text { - Accessibility } \\
\text { - Efficiency\&Proficiency }\end{array}$ & $\begin{array}{l}\text { Financial Performance and Market } \\
\text { Share of Commercial Banks }\end{array}$ \\
$\qquad$ & $\begin{array}{r}\text { Number of accounts opened } \\
\bullet \quad \text { Volume of deposits }\end{array}$ \\
\cline { 2 - 3 }
\end{tabular}

Source: Author (2016)

\section{RESEARCH METHODOLOGY}

\subsection{Research Design}

A research design is the plan, structure of investigation conceived to obtain answers to research questions that includes an outline of the research work from hypothesis, methods and procedures for collecting and analyzing data and presenting the results in a form that can be understood by all (Mugenda \& Mugenda,1999). This research problem was studied through the use of a descriptive research design. A descriptive study is concerned with finding out the what, where and how of a phenomenon (Cooper \& Schindler, 2001).

\subsection{Target Population}

Target population is defined as all the members of real or hypothetical set of people, events, or objects to which a researcher wishes to generalize the results of the study (Kothari, 2004).The target population of the study was 11 listed Commercial Banks offering M-banking in Nairobi. 


\subsection{Sample Population}

The study utilized census. Thus all the 11 respondents in the target population were involved in the study. When the population is small there is no reason for sampling if time and resources allow and this increases reliability (Mugenda,2003).

\subsection{Construction of Research Instruments}

The study utilized primary data. The data was collected by use of questionnaires. The questionnaires were divided into 5 Sections. Section A covered the respondent's profile, Section B Money service transactions, Section C covered accessibility, section D covered efficiency and proficiency and section E covered financial performance and market share.

\subsection{Piloting of Research Instruments}

The researcher carried out a pilot study to appraise the interview schedule soundness of the items and to estimate time required to answer the items. The pilot study covered some of the 6 unlisted bank who were not included in the target population. The results of the pilot study were discussed with the respondents and the required adjustments made.

\subsection{Testing For Validity \& Reliability}

\subsubsection{Reliability Test for Data Collection Instrument}

The reliability of instruments measure the consistency of instruments, Best and Khan, (2003) considers the reliability of the instruments to be the degree of consistency that the instruments or procedure demonstrates. What it measures it does so consistently. The cronbach's alpha reliability coefficient of four independent variables was obtained. In general, reliabilities less that 0.60 are considered poor, those in the 0.7 range are acceptable and those over 0.8 are good (Sekaran, 2003)

\subsubsection{Validity Test for Data Collection Instrument}

Validity is the degree to which a test measures what it purports to measure. Mugenda and Mugenda (1999), defines validity as the accuracy and meaning fullness of the inferences which are based on the research results. It is the degree to which results obtained from the analysis of the data actually represents the phenomena under study. To enhance validity the researcher consulted the supervisor for verification and appraisal of the instruments.

\subsection{Data Collection Methods and Procedures}

According to Mugenda and Mugenda (1999) questionnaires give a detailed answer to complex problems. Additionally, questionnaires are also a popular method for data collection in deduction because of the relative ease and cost-effectiveness with which they are constructed and administered. Questionnaires give a relatively objective data and therefore, are most effective. In this study, Questionnaire was used as the main instrument of data collection from the agents .Self administered questionnaires with closed and Open ended questions that was developed in line with the objectives of the study was used to enable respondents provide responses related to variables of study. The questionnaires were collected after one week for analysis.

\subsection{Ethical Considerations}

There are a number of ethical considerations to be kept in mind during the research process. First and foremost is that some of the information that this study sought to have and analyze might be considered private by the commercial banks. The respondents might give confidential and sensitive information that that should not get to the hands of the public. Our first consideration was therefore to ensure confidentiality and protect the anonymity of our respondents. All communication with respondents and any information given for the purpose of the study was treated with the strictest confidence. All the respondents to the study were coded to protect their anonymity. The research accompanied her with an explanatory letter that assured the respondent of the confidentiality of their response. Participation in the study was entirely voluntary and correspondence with the respondent contained a clear narrative describing the purpose of the study as well as a guarantee that the information provided will only be used for the purposes stated. 


\subsection{Data Analysis Techniques and Procedures}

The collected data was thoroughly examined and checked for completeness and comprehensibility. The data was then summarized and analyzed to generate descriptive statistics and inferential statistics. Data was presented using percentages and frequency tables. This ensures that the gathered information is clearly understood and interpreted.

Various attributes for system security, amount of float, agent staff retention and support by commercial banks were used to explain the relationships. Factor analysis was carried out to extract factors for each variable. The study only used questions with factor loadings greater than 0.5 for regression analysis. This is because it has generally been argued that high factor loadings indicate that the variables are best choice representative of the corresponding factor. Thereafter, correlation and regression analysis were carried out.

Correlation was used to portray the relationship between fund transfer and financial performance and market share of the listed commercial banks

Regression analysis was used to determine the effect of fund transfer on financial performance of commercial banks. The regression equation estimated is:

$$
Y=\beta_{0}+\beta_{1} X_{1}+\beta_{2} X_{2}+\beta_{3} X_{3}++\varepsilon
$$

Whereby $\mathrm{Y}=$ financial Performance and market share, $X_{1}=$ money service transaction, $X_{2}=$ accessibility, $X_{3}=$ efficiency and proficiency, while $\beta_{0}, \beta_{1}, \beta_{2}, \beta_{3}$, are coefficients to be estimated and $\varepsilon$ is the error term.

Length of service was included in the regression analysis as a control variable. This was aimed at controlling any specification errors.

\section{Data Analysis AND Findings}

\subsection{Inferential Statistics}

Correlation and poison regression analysis results are presented in this section to evaluate the relationship between fund transfer and financial performance and market share.

Before carrying out correlation and regression analysis, factor analysis was carried out to extract 3 factors namely, money service transaction, accessibility, efficiency and proficiency. Factor analysis was employed to unearth underlying factors that illustrate relationships among sets of related items. It is a preferred tool because of its ability to identify small number factors that are linked critically to the domain of interest and grouping similar structures together.

The factors for this study were labeled as money service transaction, accessibility, efficiency and proficiency. They were generated from a set of questions that illustrated stability in response. Money service transaction was loaded onto by 3 questions

Accessibility was loaded onto by 2 questions touching on challenges in maintaining adequate accessible amount. Similarly, efficiency and proficiency was loaded onto by 2 questions touching on the effects of effectiveness on operations and aptitude customer being brought about by constant change of personnel serving customers.

Table4.1. Factor loadings

\begin{tabular}{|l|l|l|}
\hline Variables & Statement in questionnaire & Factor loadings \\
\hline $\begin{array}{l}\text { Money service } \\
\text { transaction } \\
\boldsymbol{\alpha}=\mathbf{0 . 6 0 2 9}\end{array}$ & $\begin{array}{l}\text { transaction affects operations } \\
\text { Lack of security in the system leads to a feeling of insecurity } \\
\text { among customers }\end{array}$ & 0.5023 \\
& Few transactions leads to reduced number of deposits & 0.6563 \\
\hline $\begin{array}{l}\text { Accessibility } \\
\boldsymbol{\alpha}=\mathbf{0 . 6 9 9 1}\end{array}$ & Maintaining adequate amount is always a major challenge & 0.6624 \\
\hline $\begin{array}{l}\text { Efficiency and } \\
\text { proficiency }\end{array}$ & Fluctuations in amount affects agency operations & 0.7358 \\
$\boldsymbol{\alpha}=\mathbf{0 . 5 3 7 0}$ & Effectiveness & 0.5250 \\
\hline
\end{tabular}

$\alpha$ - represents Cronbach's alpha, which is the average of the average of the factor loadings in each category. 
This resulted in $\alpha=0.6029, \alpha=0.6991$, and $\alpha=0.5370$ for Money service transaction, Accessibility and efficiency and proficiency. The results indicate that all variables of interest elicited reliability which fell below the Cronbach's cut off test of 0.7. Nunnally (1978) offered a rule of thumb of 0.7 as the acceptable reliable coefficient but also argues that lower thresholds are sometimes used. This is consistent with the Hatcher (1994) argument that a construct is hypothetical variable that is being measured and that the Cronbach's alpha is an index of reliability associated with the variation accounted for by the true score of the underlying construct.

After identifying the factors, correlation and regression analysis were carried out.

\subsection{Correlation Analysis}

Correlation analysis was carried out to determine the relationships, direction and strengths between the dependent variable; financial performance and market share; and independent variables namely; Money service transaction, Accessibility and efficiency and proficiency.

From the correlation results, there was a strong positive and significant correlation between the financial performance and market share (number of accounts opened and deposits levels) and fund transfer. These findings are further manifested by the regression results.

Table4.2. Correlations Matrix

\begin{tabular}{|c|c|c|c|c|c|}
\hline & & $\begin{array}{l}\text { Money Service } \\
\text { Transaction }\end{array}$ & $\begin{array}{l}\text { Accessi } \\
\text { bility }\end{array}$ & $\begin{array}{l}\text { Efficiency And } \\
\text { Proficiency }\end{array}$ & $\begin{array}{l}\text { Financial Performance } \\
\text { \& Market Share }\end{array}$ \\
\hline \multirow[t]{2}{*}{$\begin{array}{l}\text { Money Service } \\
\text { Transaction }\end{array}$} & $\begin{array}{l}\text { Pearson } \\
\text { Correlation }\end{array}$ & 1 & & & \\
\hline & \multicolumn{2}{|l|}{ Sig. (2-tailed) } & & & \\
\hline \multirow[t]{2}{*}{ Accessibility } & \begin{tabular}{|l|} 
Pearson \\
Correlation
\end{tabular} & $.373 * *$ & 1 & & \\
\hline & Sig. (2-tailed) & .000 & & & \\
\hline \multirow[t]{2}{*}{$\begin{array}{l}\text { Efficiency And } \\
\text { Proficiency }\end{array}$} & \begin{tabular}{|l|} 
Pearson \\
Correlation
\end{tabular} & $.303 * *$ & $.334 * *$ & 1 & \\
\hline & Sig. (2-tailed) & .000 & .000 & & \\
\hline \multirow[t]{2}{*}{$\begin{array}{l}\text { Financial } \\
\text { Performance \& } \\
\text { Market Share } \\
\end{array}$} & $\begin{array}{l}\text { Pearson } \\
\text { Correlation }\end{array}$ & $.330 * *$ & $.373 * *$ & $.333 * *$ & 1 \\
\hline & Sig. (2-tailed) & .000 & .000 & .000 & \\
\hline
\end{tabular}

A significant positive correlations were found to exist between various service transactions and Financial Performance \& Market Share $(r=0.330, p=0.000)$. Better still, there existed a more strong positive significant correlation between accessibility and Financial Performance \& Market Share $(\mathrm{r}=0.373, \mathrm{p}=0.000)$ and Efficiency and Proficiency $(\mathrm{r}=0.333, \mathrm{p}=0.000)$,

\subsection{Regression Analysis}

In this study a multiple linear regression model was employed to pinpoint the affiliation between the three independent variables and the dependent variable. The study applied the statistical package for social sciences (SPSS) to code, enter and compute the dimensions of the multiple regressions for the study.

Table4.3. Regression Model Summary

\begin{tabular}{|l|l|l|l|}
\hline R & R Square & Adjusted R Square & Std. Error of the Estimate \\
\hline $0.720^{\alpha}$ & 0.518 & 0.514 & 0.54947 \\
\hline
\end{tabular}

The adjusted $\mathrm{R}^{2}$ is the coefficient of determination. The three independent variables that were studied, explain $51 \%$ of the effect of debt financing on profitability of licensed commercial banks in Kenya as represented by the $\mathrm{R}^{2}$. This therefore means that other factors not taken into consideration in this study contribute to $49 \%$ of the effect of fund transfer on financial performance and market share of listed commercial banks in Kenya giving room for further research to investigate the other factors. In statistics significance testing the p-value indicates the level of relation of the independent variable to the dependent variable. If the significance number found is less than the critical value also known as the probability value $(\mathrm{p})$ which is statistically set at 0.05 , then the conclusion would be that the model is significant in explaining the relationship. 


\subsection{Summary of the Test of Hypothesis}

Following the analysis findings, accessibility indicated the highest positive impact on financial performance and market share while efficiency and proficiency followed and money service transaction had the least positive impact on financial performance and market share commercial banks.

$\mathbf{H}_{01}$ : Money Services Transactions have no significant effect on financial performance and market share of commercial banks in Kenya. The results indicated a $\beta$ value of 0.711 with a p-value of 0.017 thus the study rejected hypothesis one and concluded that Money Services Transactions positively affected the financial performance and market share of commercial banks in Kenya.

$\mathbf{H}_{\mathbf{0 2}}$ : Accessibility to mobile money services has no significant effect on financial performance and market share of commercial banks in Kenya. The results indicated that Accessibility to mobile money services had a $\beta$ value of 0.837 with a p-value of 0.001 thus the study rejected hypothesis and concluded that Accessibility to mobile money services positively affected the financial performance and market share of commercial banks in Kenya.

$\mathbf{H}_{03}$ : Efficiency and Proficiency have no significant effect on financial performance and market share of commercial banks in Kenya. The results indicated that Efficiency and Proficiency had a $\beta$ value of 0.763 with a p-value of 0.012 thus the study rejected hypothesis and concluded that positively affected the financial performance and market share of commercial banks in Kenya.

\section{Conclusions}

The outcome attained from the regression equation showed there is a significantly positive relationship between fund transfer and financial performance and market share of commercial banks in Kenya. Based on the descriptive analysis namely Money service transaction, Accessibility and efficiency and proficiency were cited as the main influences of fund transfer and subsequent financial performance and market share of commercial banks. It is evident therefore that without proper consideration of the above aspects the performance of M-banking will not be at its optimal level. Regression analysis confirmed significant relationship with the variables of interest.

\section{RECOMMENDATION FOR FURTHER RESEARCH}

Since the study could not evaluate all possible factors that contribute to financial performance and market share of commercial banks, further research is recommended. More needs to be done on this area on other non-financial aspects of M-banking other than level of deposits and number of accounts opened.

The study recommends an in-depth study to be carried out on the challenges faced by savings and credit cooperative societies in adopting mobile banking in the banking industry in Kenya. These challenges include macroeconomic factors such as political unrest, interest rates, labour unrest and social-cultural perspective would need to be analyzed for clear results. Further, the study recommends that a similar study should be conducted among the mobile service provider companies to find out whether it will yield the same results.

\section{REFERENCES}

Best, J., \& Khan, J. (2003). Research In Education. Boston: Allyn \& Bacon.

Bisignano, J. (1992). Banking competition, regulation and the philosophy of financial development: a search for first principles,' in the internationalization of capital markets and the regulatory response, John Fingleton (ed.). London: Graham and Trotman.

Cooper, D., \& Schindler, P. (2001). Business Research Method. Washington: Macmilan.

Ignacio, M. (2009). The Economics of Branchless Banking. . Innovations: Technology, Governance, Globalization Vol.4, no.2.

Ivatury, G., \& Lyman, T. (2006). Use of Agents in Branchless Banking for the Poor: Rewards, Risks, and Regulation. Washington D.C: CGAP Focus Note No. 38: October.

Kamau, J. (2012). The Relationship Between Agency Banking and Financial Performance of Commercial Banks in Kenya. MBA Project,University of Nairobi, 20-23.

Kimenya, M. (2002). The Nature, Distribution and Evolution of Poverty and Inequality in Uganda. Journal of Finance, 50-55. 
Influences of Fund Transfer on Financial Performance and Market Share of Commercial Banks Listed At the Nairobi Securities Exchange, Kenya

Mugenda, O. (2003). Research Methods: Quantitative and qualitative approaches. Nairobi: Acts Press.

Mugenda, O., \& Mugenda, A. (1999). Research methods: Quantitative and Qualitative Approaches. Nairobi: Acts Press Publishing.

Mwangi, R. (2011). An Evaluation of The Role Of Agency Banking In The Performance of Commercial Banks In Kenya. MBA Thesis, Kenyatta University, 45-48.

Orodho, A. (2009). Essentials of education and social sciences research methods. Nairobi: Masode Publishers.

Owens, J. (2006). RBAP Text-A-Payment And G-Cash Cash-In/Cash-Out Services Innovative Banking Services At Your Fingertips. Journal of Finance, 12-15.

Sekaran, U. (2003). Research methods for business: A skill buildings approach. 4th Ed. New York: John \& Willey.

Sohail, M. and Shanmugham, B. (2003) E-banking and customer preferences in Malaysia: An empirical investigation, Information Sciences, Vol. 150, No. 3/4:207-217, 2003.

Tiwari, R. Buse, S and Herstatt, C. (2006) Mobile Banking As Business Strategy: Impact of Mobile Technologies on Customer Behaviour and Its Implications for Banks, Mobile Banking As Business Strategy: Impact Of Mobile Technologies on Customer Behaviour and Its Implications for Banks. Working Paper No. 37.Presented at "Portland International Conference on Management of Engineering and Technology" (PICMET) 2006, 8 - 13 July 2006, Istanbul (Turkey).

Tomaškova, H. (2010). M-Commerce And M-Banking Focused On Czech Republic. Communication And Management In Technological Innovation And Academic Globalization, 30-35.

\section{AUTHOR's BIOGRAPHY}

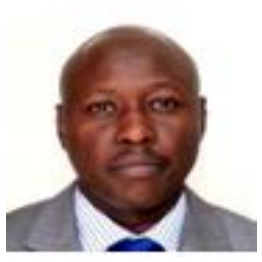

A proactive and inspirational professional who consistently achieves and exceeds on business objectives. Dynamic and focused as a team player and equipped by experience and training to deliver high performance in demanding work environments. 